Bangladesh J. Bot. 49(3): 585-591, 2020 (September)

\title{
EFFECTS OF LONG TERM USE OF ORGANIC AND INORGANIC FERTILIZERS ON SOIL FERTILITY AND PRODUCTIVITY UNDER PADDY - SESAME CROPPING SYSTEM
}

\author{
Ashok Kumar Gaddi*, MA Basavanneppa and Prabhuling Tevari \\ Main Centre for AICRP-IFS, Agricultural Research Station, Siruguppa-583 121, Ballari (Dst.), \\ University of Agricultural Sciences, Raichur, Karnataka, India
}

Keywords: Long term use, Inorganic, Fertilizer, Soil organic carbon, Rice equivalent yield

\begin{abstract}
A field study was conducted to analyze the effect of long term use of organic and inorganic fertilizers on productivity and soil fertility under paddy-sesame cropping system. Application of $100 \%$ NPK + secondary and micro-nutrients based on soil test $\left(\mathrm{T}_{7}\right)$ showed significantly higher mean grain yield of paddy $(4735$ $\mathrm{kg} / \mathrm{ha})$ and sesame $(460 \mathrm{~kg} / \mathrm{ha})$ and rice equivalent yield $(5348 \mathrm{~kg} / \mathrm{ha})$ followed by application of $50 \% \mathrm{NPK}+$ $50 \% \mathrm{~N}$ as Farmyard manure $(\mathrm{FYM})+$ inorganic source of micronutrients as per soil test $\left(\mathrm{T}_{1}\right)$. Whereas, application of $50 \%$ recommended dose of nitrogen (RDN) through FYM + bio-fertilizers for $\mathrm{N}+$ Recommended dose of phosphorus (RDP) through rock phosphate + phosphorus solubalizing bacteria (PSB) showed significantly least mean grain yield of paddy $(3209 \mathrm{~kg} / \mathrm{ha})$ and sesame $(314 \mathrm{~kg} / \mathrm{ha})$ and rice equivalent yield $(3628 \mathrm{~kg} / \mathrm{ha})$. Further, among organic treatments $\left(\mathrm{T}_{2}\right.$ to $\left.\mathrm{T}_{6}\right)$, higher mean grain yield of paddy $(3834 \mathrm{~kg} / \mathrm{ha})$, sesame $(326 \mathrm{~kg} / \mathrm{ha})$ and rice equivalent yield $(4269 \mathrm{~kg} / \mathrm{ha})$ as compared to other treatments was recorded following the application of one third of RDN through FYM + one third of RDN through vermicompost + one third of RDN through neem cake + bio-fertilizers containing $\mathrm{N}$ and $\mathrm{P}$ carriers $\left(\mathrm{T}_{6}\right)$. Whereas, higher nutrient status with respect to major and micronutrients and the improved soil fertility status was recorded in organic treatment plots. The application of nutrients through organic sources would improve the soil fertility status under paddy-sesame cropping system.
\end{abstract}

\section{Introduction}

In the recent past synthetic fertilizer became a target of criticism, mainly because of its heavy use in the developed countries that having an adverse impact on the environment through nitrate leaching, eutrophication, greenhouse gas emission, heavy metal uptake by plants and also led to multi-nutrient deficiencies. Their deficiencies are continuously increasing particularly $\mathrm{Zn}, \mathrm{B}, \mathrm{Fe}$, $\mathrm{Mn}, \mathrm{Cu}, \mathrm{Mo}$ in addition to sulphur (Bumb and Baanante 1996). Later in order to avoid hazards on soil by heavy use of inorganic fertilizers in the mid 1990s, the concept was developed in the developing country like India i.e., integrated nutrient management (INM) that includes inorganic, organic and bio-fertilizers, later augment the use efficiency of applied fertilizers to soil along with building of fertility in soil. This helps to explore the alternative potential source of plant nutrients with minimal use of mineral fertilizers. Organic matter is of great importance for the maintenance of soil structure, soil bioactivity, soil cation exchange capacity and water holding capacity (NFDC 1998).

Rice is the most important cereal crop next to wheat in the world. In India, it ranks first in area and production. In the world it is grown over an area of $161.4 \mathrm{~m}$ ha with an annual production of 479.3 million tones with a productivity of $4400 \mathrm{~kg} / \mathrm{ha}$. In India, it is cultivated over an area of $43.9 \mathrm{~m}$ ha with an annual production of 106.3 million tones and with a productivity of $2419 \mathrm{~kg} / \mathrm{ha}$ (Anon. 2016-17). In Karnataka, it occupies an area of 14.1 lakh hectares with a total production of 39.5 lakh tones and productivity of $2940 \mathrm{~kg} / \mathrm{ha}$ (Anon. 2016-17).

*Author for correspondence: <gaddisoil@gmail.com>. 
Rice-based cropping systems form an integral part of agriculture in Karnataka. Several intensive rice based cropping systems have been identified and are being practiced by the farmers. Intensive agriculture practices involving high yielding varieties of rice and other crops resulted in heavy withdrawal of nutrients from the soil coupled with imbalanced and discriminate use of chemical fertilizers resulted in deterioration of soil health (John et al. 2001). Continuous cropping results in rapid decline in soil fertility and thus requires a special attention.

Adequate nutrient supply through inorganic and organic fertilizers source for better rice production and sustaining the soil health is a high priority. Integrated use of inorganic and organic source of plant nutrients has a tremendous potential not only in sustaining agricultural productivity and soil health but also in substituting a part of fertilizer requirement by organics. In order to improve the supplies of all the essential plant nutrients and also to maintain soil health, it is necessary to use organic and bio-fertilizers viz., FYM, vermicompost, neem cake etc., and in conjunction with inorganic fertilizers (Subramaniyan et al. 2000). Therefore, the present investigation was carried out to find out the effect of long term use of organics on yield and soil fertility under paddy-sesame cropping system in north eastern dry zone (Zone-III) of Karnataka state.

\section{Materials and Methods}

The organic farming experiment was initiated during 2003-04 at Agricultural Research Station, Siruguppa, USA, Raichur in a non replicated design with an plot size of $17 \mathrm{~m} \times 18 \mathrm{~m}$ on rice-sesame cropping system. The experiment was conducted at vertisol soil type and soils are clayey in texture. The soils are slightly alkaline in soil reaction (8.09) and low in soluble salt concentration $(0.39 \mathrm{dS} / \mathrm{m})$. The soils were high in organic carbon content $(0.59)$ and low in available $\mathrm{N}(221 \mathrm{~kg} / \mathrm{ha})$, and medium in available $\mathrm{P}(24.5 \mathrm{~kg} / \mathrm{ha})$ and rich in available potassium (324 kg/ha) and overall status indicates soils are low to high in fertility. The rice crop was grown during kharif (5th August) and followed by sesame during summer (15th December) and varieties used for study were Mugad suganda for rice crop and TDSS-9 for sesame crop. The recommended dose of fertilizer (RDF) used for rice crop was $150: 75: 75 \mathrm{~kg}$ NPK/ha as per the package of practices recommended for Zone-III of Karnataka. The experiments composed of treatments viz., $\mathrm{T}_{1}: 50 \% \mathrm{NPK}+50 \% \mathrm{~N}$ as FYM + inorganic sources of micronutrients as per soil test, $\mathrm{T}_{2}:{ }^{1} /{ }_{3} \mathrm{RDN}$ $(\mathrm{FYM})+1 / 3 \mathrm{RDN}(\mathrm{VC})+1 / 3 \mathrm{RDN}$ (Neem cake), $\mathrm{T}_{3}: \mathrm{T}_{2}+$ intercropping or trap crop, $\mathrm{T}_{4}: \mathrm{T}_{2}+$ agronomic practices for weed and pest control, $\mathrm{T}_{5}: 50 \% \mathrm{RDN}(\mathrm{FYM})+$ bio-fertilizer for $\mathrm{N}+\mathrm{RDP}$ (Rock phosphate) $+\mathrm{PSB}, \mathrm{T}_{6}: \mathrm{T}_{2}+$ bio-fertilizer containing $\mathrm{N}$ and $\mathrm{P}$ carriers and $\mathrm{T}_{7}: 100 \% \mathrm{NPK}+$ secondary and micronutrients based on soil test.

The sesame crop was grown as a residual crop without applying any fertilizers. The year wise, yield was recorded for both crops and also rice equivalent yield $(\mathrm{kg} / \mathrm{ha})$ was calculated considering the price of both the crops in the respective year and it is calculated using the formula REY $(\mathrm{kg} / \mathrm{ha})=\{[$ Grain yield of rice $(\mathrm{kg} / \mathrm{ha})]+[($ Grain yield $(\mathrm{kg} / \mathrm{ha})$ of Sesame $\times$ price of sesame (Rs)/price of rice] $\}$. To arrive, SEm \pm and CD, the RBD analysis (Gomez and Gomez 1984) was carried out taking into consideration of year as replication against number of treatments from 2008 - 09 to 2012 - 13. Data were assessed by DMRT (Duncan 1955) with a probability ( $<<0.05)$. The year- and treatment wise surface soil samples from $0-15 \mathrm{~cm}$ depth were collected for soil fertility assessment. The post harvest soils collected were analyzed for their soil $\mathrm{pH}$ and $\mathrm{EC}(\mathrm{dS} / \mathrm{m})$ in 1 : 2.5 soil to water ratio as described by Jackson (1958). The soil organic carbon was determined by wet oxidation method as described by Walkely and Black (1965). Similarly, the soil available nitrogen was determined by alkaline permanganate method as outlined by Subbiah and Asija 
(1959). Available phosphorus was determined by Olsen method and available potassium was determined by neutral normal ammonium acetate solution using flame photometer as outlined by Jackson (1958).

\section{Results and Discussion}

The mean grain yield of rice, sesame and rice equivalent yield were significantly influenced by the application of $100 \%$ NPK + secondary and micronutrients application based on soil test $\left(\mathrm{T}_{7}\right)$ over the combination of inorganic and organic fertilizers in combination and organics in alone (Tables 1 and 2). Results revealed that, application of 100\% NPK + secondary and micro-nutrients based on soil test showed significantly higher mean grain yield of paddy $(4735 \mathrm{~kg} / \mathrm{ha})$ and sesame (460 kg/ha), and rice equivalent yield $(5348 \mathrm{~kg} / \mathrm{ha})$ as compared to other treatments. Whereas, application of 50\% RDN through FYM + bio-fertilizers for N + RDP through rock phosphate + PSB $\left(\mathrm{T}_{5}\right)$ showed significantly least mean grain yield of paddy (3209 kg/ha) and sesame (314 $\mathrm{kg} / \mathrm{ha}$ ) and rice equivalent yield (3628 kg/ha). Further, among organic treatments $\left(\mathrm{T}_{2}\right.$ to $\left.\mathrm{T}_{6}\right)$, application of one third of RDN through FYM + one third of RDN through vermicompost + one third of RDN through neem cake + bio-fertilizers containing $\mathrm{N}$ and $\mathrm{P}$ carriers $\left(\mathrm{T}_{6}\right)$ showed higher mean grain yield of paddy $(3834 \mathrm{~kg} / \mathrm{ha})$, grain yield of sesame $(326 \mathrm{~kg} / \mathrm{ha})$ and rice equivalent yield $(4269 \mathrm{~kg} / \mathrm{ha})$ as compared to other treatments. On the contrary seed yield of sesame was almost stable with application of inorganic and organic fertilizers alone or in combination. The higher rice and sesame yield with application of inorganic fertilizers might be due to the higher and quickly availability of nutrient from the inorganic fertilizers, whereas, due to the mismatch of nutrients release from the organic sources and crop demand as influenced by seasonal conditions in the initial years might have caused the lower yield in organic fertilizer use treatments. A 20 $30 \%$ less yield of crops in organic farming was reported by Rajendraprasad (2006) and significantly reduction in rice yield of $15-20 \%$ in the initial years by the application of organics when compared to inorganic sources was observed by Surekha et al. (2010). The application of Zn and sulphur based on the soil test values along with the supply of major mineral fertilizers viz., NPK might have maintained higher yields over years than the organic fertilizer application. The substitution of organic fertilizers viz., vermicompost, FYM and neem cake for the inorganic fertilizers over period did not influence much the yield levels of rice and sesame in inorganic fertilizer treated plots. These results were in conformity with the findings of Sharma and Singh (2004) who reported the recession to the crop yields during initial phase of transition from conventional to organic agriculture and recovery in yields after $2-3$ years.

The soil nutrient status (Tables 3 and 4) indicated that there was significant increase in the organic carbon content and available nitrogen in soil by the application of organic fertilizers $\left(T_{2}\right.$ to $\mathrm{T}_{6}$ ) and in combination of organic and inorganic fertilizers $\left(\mathrm{T}_{1}\right)$. However, the use of inorganic fertilizers $\left(\mathrm{T}_{7}\right)$ alone recorded lower content of organic carbon $(0.67 \%)$ and did not influence its increase much in the soil. The organic carbon and available nitrogen content in soil ranged from 0.67 to 0.97 per cent and 219 to $235.6 \mathrm{~kg} / \mathrm{ha}$, respectively. This is mainly due to the organics, which are rich in organic carbon and might have involved in the buildup of soil micro flora and resulted in the higher available nitrogen content in soils. However, relatively higher content of available $P$ and $K$ were also observed in the organic treated plots $\left(T_{2}\right.$ to $\left.T_{6}\right)$ and in combination of organic and inorganic plots $\left(\mathrm{T}_{1}\right)$ when compared to inorganic applied plots $\left(\mathrm{T}_{7}\right)$ and they were at par with each other. However, the per cent average increase in organic carbon buildup in soil by use of organic fertilizers was observed to the tune of 19.1 - 38.2 per cent and available $\mathrm{P}$ to the extent of $10.4-27.0$ per cent when compared to the inorganic treated plots $\left(\mathrm{T}_{7}\right)$. The numerically higher content of $\mathrm{P}$ and $\mathrm{K}$ was also observed in the organic and organic + inorganic treatments (Table 3). In contrast, the micronutrient content of $\mathrm{Zn}$ (Table 5) was higher $(1.1 \mathrm{mg} / \mathrm{kg})$ in 


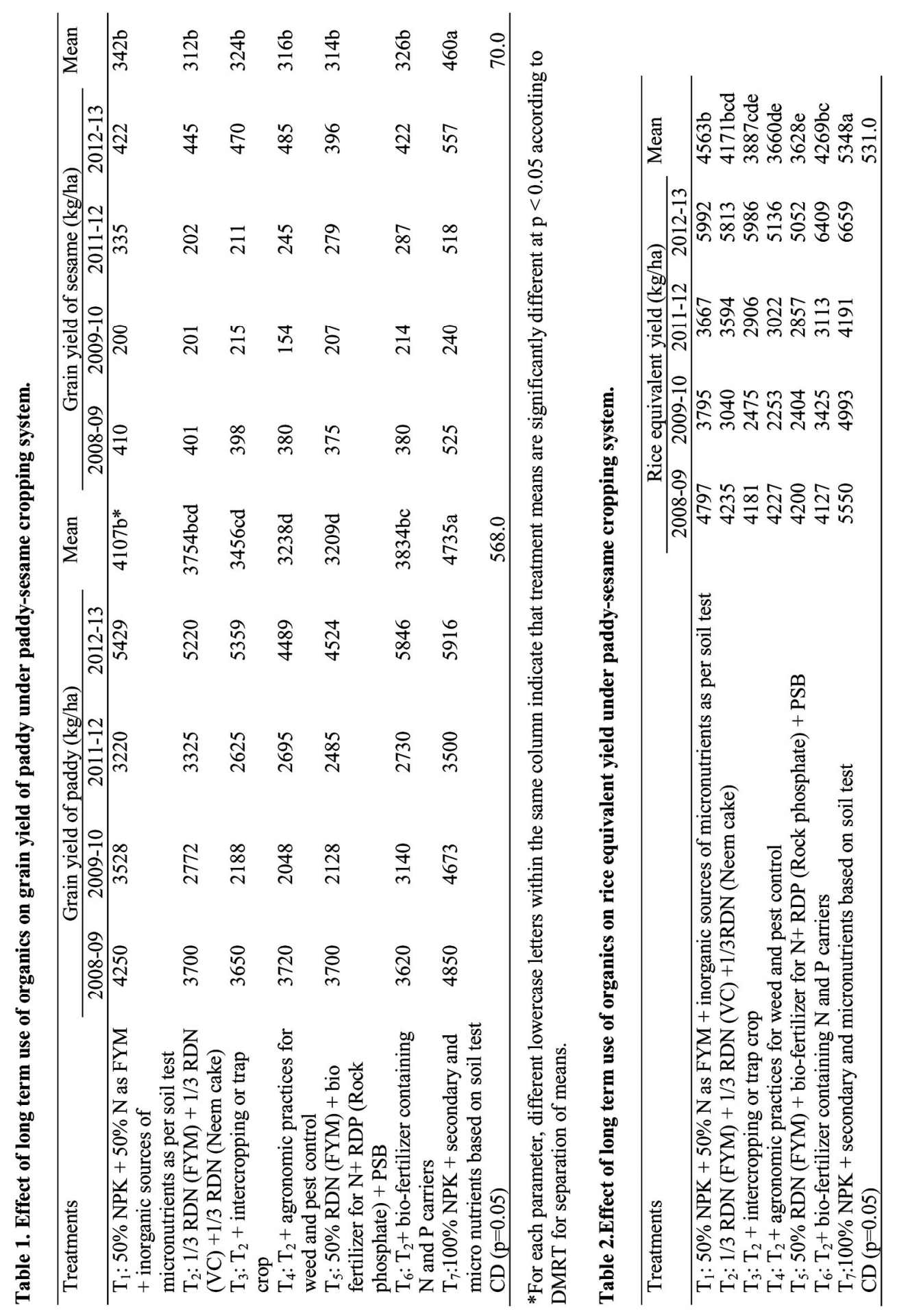




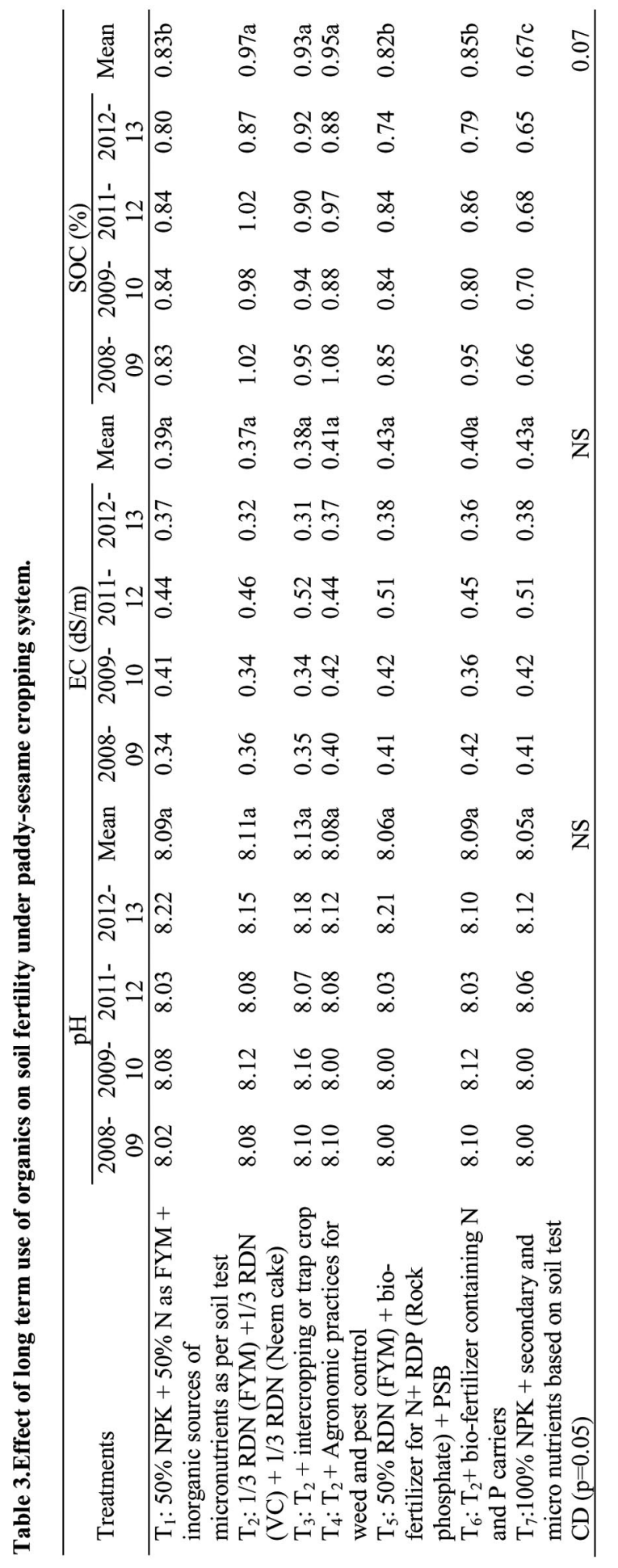



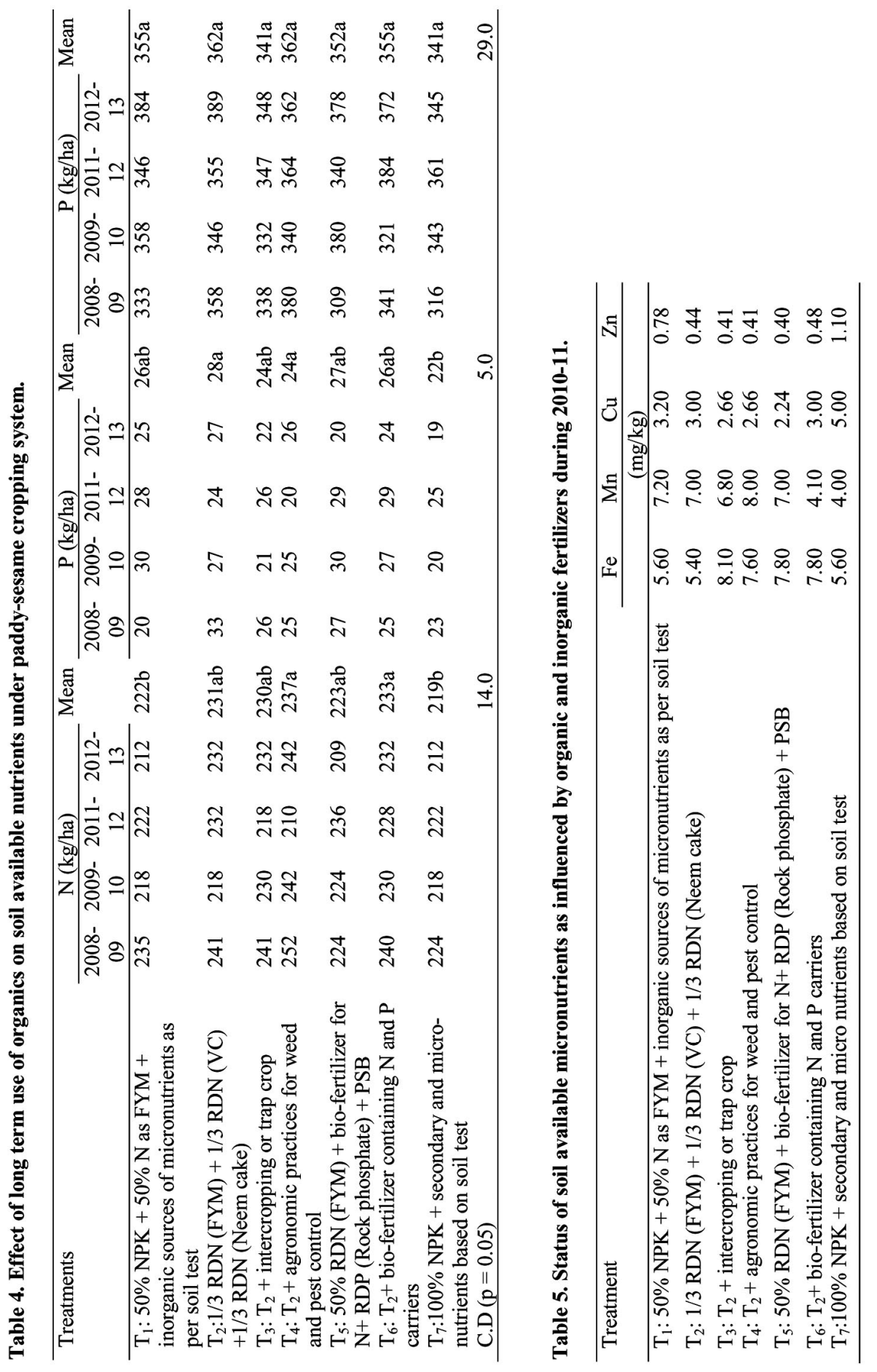
inorganic treated treatment $\left(\mathrm{T}_{7}\right)$ and it was followed by $\mathrm{T}_{1}(0.78 \mathrm{mg} / \mathrm{kg})$. The increase in organic carbon due to application of FYM has been observed by More (1994) and improvement of soil organic carbon in soils of Ranchi by use of organic and inorganic fertilizers was also reported by Sarkar et al. (2000). Although, the increase in the fertility status of soil by use of organics does not have influence on the SEY over inorganic fertilizers.

Based on long term experimentation, it can be concluded that, the grain yield of rice and sesame and rice equivalent yield (REY) were significantly influenced by the application of $100 \%$ NPK + secondary and micro nutrients application based on soil test $\left(\mathrm{T}_{7}\right)$ and in combination of organic and inorganic fertilizers i.e., 50\% NPK $+50 \% \mathrm{~N}$ as FYM + inorganic sources of micronutrients as per soil test $\left(\mathrm{T}_{1}\right)$ over the organics. Soil nutrient status viz., soil organic carbon content and available nitrogen in soil increased significantly and relatively higher content of available $P$ and $K$ by the application of organic fertilizers in alone $\left(T_{2}\right.$ to $\left.T_{6}\right)$ and in combination of organic and inorganic fertilizers $\left(\mathrm{T}_{1}\right)$ when compared to inorganic fertilizers $\left(\mathrm{T}_{7}\right)$.

\section{References}

Anonymous 2016-17. India budget, Economic Survey (http://indiabudget.nic.in/survey.asp)

Bumb BL and Baanante CA 1996. Policies to promote environmentally sustainable fertilizer use and supply to 2020. IFRI Policy paper 40, Washington DC.

Duncan DM 1955. Multiple ranges and multiple F-tests. Biometric 11: 1-42.

Gomez KA and Gomez AA 1984. Statistical procedures for agricultural research, 2nd Edn. John Wiley and sons, New York, p 680.

Jackson ML 1958. Soil Chemical Analysis. Prentice Hall of India. Private Ltd., New Delhi.

John PS, George M, Jacob R (2001). Nutrient mining in agro-climatic zones of Kerala. Fertilizer News, 46: 45-52, 55-57.

More SD 1994. Effect of farm wastes and organic manures on soil properties, nutrient availability and yield of rice-wheat grown on sodic-Vertisols. J. Indian Soc. Soil Sci. 42: 253-256.

National Fertilizer Development Centre (NFDC) 1998. Integrated Plant Nutrition System (IPNS). NFDC technical report 3/98, p 30. Planning and Development Division. National Fertilizer Development Centre, Islamabad, Pakistan.

Rajendraprasad 2006. Organic farming. Indian Farming 55: 4-6.

Sarka KA, Singh KP, Singh BP and Singh RP 2000. Long-term effects of fertilizers, manures and amendments on crop production and soil fertility. SSAC (BAU) Tech. Bull. 2/2000, pp. 44-48.

Sharma PD and Mohan Singh 2004. Problems and prospects of organic farming. Bulletin of the Indian Soc. of Soil Sci. 22: 14-41

Subbiah BV and Asija CL 1959. A rapid procedure for estimation of available nitrogen in soils. Curr. Sci., 25: $259-260$.

Subramaniyan K, Kalaiselvan P and Arulmozhi N 2000. Studies on the effect of nutrient spray and graded level of NPK fertilizers on the growth and yield of groundnut. International. Tropical Agril. 18(3): 287-290.

Surekha K, Jhansilakshmi V, Somashekhar N, Latha PC, Kumar RM, Shobha Rani N, Rao KV and Virakthamath BC 2010. Status of organic farming and research experiences in rice. J. Rice Res. 3(1): 23-35

Walkely and Black CA 1965. Methods of Soil Analysis. Vol. I., Amer. Soc. Agron. Madison. Wisconsin. USA. 